\title{
İlk Dönem Kazakistan Cumhuriyeti'nde Milliyetçilik ve Millî Kimlik (1991-2019) $^{1}$
}

\author{
Hikmet DEMÍRCi \\ Dr. Öğr. Üyesi, Kahramanmaraş Sütçü İmam Üniversitesi, \\ Fen Edebiyat Fakültesi, Tarih Bölümü \\ hdemirci@ksu.edu.tr \\ Orcid ID: https://orcid.org/0000-0001-8756-5909
}

\begin{abstract}
Öz
Milliyetçilik, belirli topraklar üzerinde kültür, tarih, dil gibi ortaklıklarla milletin varlığından ve değerlerinden beslenen, milletin yaşamasını, ilerlemesini sağlayan şuur, duygu veya siyasî hedeftir. Kimlik ise bir insanın veya topluluğun var olmas1, toplumun değerleri benimseyerek millî aidiyet hissetmesidir. $\mathrm{Bu}$ makale, Nursultan Nazarbayev'in milliyetçiliği (1991-2019) ve Kazak millî kimliğinin şekillendirilmesinde Türklük, tarih, din, laiklik, hukuk, alfabe değişikliği, azınlıkların durumu bakımından ortaya konan yasa ve uygulamaların değerlendirilmesidir. Nazarbayev'in amacı ortaya konan yasa ve uygulamalarla devlet-toplum ilişkilerinde etnik, ideolojik, dinî-mezhepsel ayrımcılı̆̆ın önüne geçerek çağdaş, medenî ve bağımsız bir düzene Kazakistan'1 kavuşturmaktı. Kazakistan'da millî kimlik inşası, makro düzeyde ulusal devlet düzeni Kazakistanlılık kavramı ile mikro düzeyde ise milliyetçiliği destekleyen Kazaklık anlayışıyla şekillendirildi. Kazaklık kavramı sadece tarihe, kültüre ve millî gelişime vurgu yapmadı aynı zamanda azınlıkların devlete bağlılık duygularını tahkim etme noktasında ele alındı. İlk dönem Kazakistan Cumhuriyeti'nin millî kimlik gelişiminde, Kazak Hanlığına ve tarihsel- kültürel kimliğe bağl1lık esas alındığg görüldü.
\end{abstract}

Anahtar Kelimeler: Nursultan Nazarbayev, Kazakistan, Kazaklar, Milliyetçilik, Millî Kimlik.

\footnotetext{
${ }^{1}$ Makale Geliş/Kabul Tarihi: 31.12.2019 / 09.04.2020

Künye Bilgisi: Demirci, H. (2020). İlk Dönem Kazakistan Cumhuriyeti’nde Milliyetçilik ve Millî Kimlik (1991-2019). Kahramanmaraş Sütçü İmam Üniversitesi Sosyal Bilimler Dergisi, 17 (1), 321-342. DOI: 10.33437/ksusbd.668301
} 


\title{
The Nationalism and National Identity in the First Period of the Republic of Kazakhstan (1991-1919)
}

\begin{abstract}
Nationalism can be defined as a consciousness, political goal or a feeling of belonging to a nation that formed on the basis of at he shared characteristics such as culture, history and language. The identity refers to the existence of a person or community and feeling of national belonging by adopting the values of the society. This article deals with the nationalist policy of Nursultan Nazarbayev (1991-2019) and the role of laws and practices shaped by Turkishness, history, religion, secularism, law, alphabet change, and status of minorities in shaping Kazakh national identity. Nazarbayev's aim was to create a modern, civilized and independent order by preventing all kinds of ethnic, ideological, religioussectarian discrimination in state-society and individual relations with the laws and practices enacted. The national identity in Kazakhstan was shaped by the "Kazakhism" at the macro level and by the concept of "Kazakh" that supports nationalism at micro level. The concept of Kazakh not only emphasized history, culture and national development, it was addressed in term of reinforcing minority feelings of loyalty to the state. The commitment to Kazakh Khanate and historical-cultural identity was taken as the basis in the development of national identity in the first period in Kazakhstan.
\end{abstract}

Keywords: Nursultan Nazarbayev, Kazakhstan, Kazakhs, Nationalism, National Identity.

Giriş

Fransız Devrimi sonucunda imparatorluklar dağılarak yerini ulus devletlerin alması milliyetçiliğin önemli sonuçlarından biridir. Bu noktada Sovyetler Birliği’nin dağılmasının ardından ortaya çıkan Cumhuriyetçi Türk devletleri kimliklerini millîyetçi şuur ve duygularla inşa etmeye çalıştı. Kazakistan’da hem Rus politikaları hem de kozmopolit nüfus yapısından kaynaklanan milliyetçilik ve millî kimlik algısının inşa edilmesi önemli bir problemdi. Çarlık ve Sovyet Rusya dönemlerinde "Ruslaştırma" veya "Sovyet insanı" hedefine maruz bırakılmaları sonucu ortaya çıkan değişimlerle bağımsızlıktan sonra şekillenecek politikalar cumhuriyetlerin geleceklerine yön verdi.

XIX. yüzyıldan bu yana dünya siyasi tarihini derinden etkileyen milliyetçilik, siyasi bir gruba aidiyet bilincinin kazandırılması, bir ulusun bağımsız devlet 
halîne gelmesi, millî özgüvenin gelişmesi ve güçlendirilmesinde önemliydi. Milliyetçilik; Doğulu, Batıll, modern, siyasi-kültürel, iradeci, ayrılıkçı, reformcu gibi farklı sınıflandırmalarla ele alındı. Bu kavramın, devlet, ulus, ideoloji, tarih, din, dil, kültür, etnik ve kimlikle ilişkisi olduğu gibi olumsuz manada terör, şiddet, ayrımcılık, ırkçılık gibi kavramla da ilişkisi sebebiyle de zararlı veya faydalı olarak değerlendirildi (Alakel, 2011: 2-3). Ayrıca milliyetçiliğin ilk defa Avrupa'da yorumlanmasıyla Fransız ve Alman milliyetçilik tarzları ortaya çıktı. Alman tarzı milliyetçilik etnik ve kültürel temele dayanırken Fransız tarzı daha erken dönemlerde ortaya çıkan devlet temelli yani devletin yurttaşı olmak, kader birliğini benimsemek veya o millette bağl1lık zorunluluğunu getirdi. Fransız tarzında etnik ve dinî unsurlar ise ikinci plandaydı (Kılıç, 2007: 117). Bu nedenle Kazakistan'ın ilk Cumhurbaşkanı Nazarbayev dönemi milliyetçiliği, daha ziyade Fransız tarzı milliyetçilik olarak görülse de tamamıyla bu tarza bağlılığı yoktu. Çünkü zaman içerisinde kimlik inşasında politika ve uygulamalarda Alman tarzı milliyetçiliği benimsediği de görüldü.

Kazak kimliğinde tarihî süreç ve dönemler önemli rol oynadı. Mesela Kazakların erken dönem Türk kültür coğrafyasında bulunmaları ve XV. yüzyılın ikinci yarısından itibaren Kazak Hanlı̆ğın kurulması millî kimliğin tarihe dayanan noktası olarak önemliydi. Ardından yaşanan Rus işgal süreci, Türkistan coğrafyası içerisindeki Türk topluluklarını bir bütün içerisinde ayrıştırmaya, yerlileştirmeye ve özelleştirmeye dayalı politika ve uygulamalara maruz bırakıldı. Türkistan'daki Türk halkları arasında ayrıştırmanın gerçekleşmesi, Türk toplulukları arasında birliğin dağılmasına yol açtı. Bu baskılar her ne kadar olumsuz olarak adlandırılsa da Türk topluluklarında kültür ve kimliklerine dair farkındalık eğiliminin ve korunmacı tavırların artmasıyla sonuçlandı. O dönem içerisinde tamamen bir değişim- dönüşüm veya "mankurtlaşma" dediğimiz kimliklerini unutmak yerine günümüz bağımsız Türk Cumhuriyetlerinin meydana gelmesini sağladı (Demirci, 2013: 289).

Sovyet sonrası birlik içerisindeki devletlerin bağımsızlıklarını ilan etmesiyle millî devletin yöneticileri millî kimlik politikalara ağırlık verdi. Millî kimlik politikaları ortaya çıkaran neden ise milliyetçilik idi. Mustafa Çalık'ın milliyetçilik tanımında "Milliyetçilik, başı geçmişte gömülü, kolları ve ayakları şimdiki zamanda hareket edebilen, ölüsü ve dirisi zaman zaman birbirine karışabilen yahut birbiriyle yer değiştirebilen, hayli garip bir organik varlıktır. Kesin olan o da bugün varlığı tartışmasız olan bu kimlik iddialarının hiçbirinin bugünün eseri olmadığıdır.” (Karadağ ve Yaman, 2018: 106). Bu açıdan Nursultan Nazarbayev başkanlığındaki Kazakistan Cumhuriyeti, kimliklerine tarih, kültür ile besleyerek millî köklerine bağlanma şeklinde bir süreç yaşadı.

Millîyetçi şuur üzerine kurulan Kazakistan Cumhuriyet'i yapılan yasa ve reformlarla millî kimliğin inşasına uygun konumlandırıldı. Bu yönetimde iki 
kavram öne çıktı: "Kazakistan Milleti” ve "Kazaklık". Kazakistan Milleti ile Kazaklık (etnik Kazak kimliği) kavramı üzerine iki cepheli tartışmalar, Kazak halkının kendini tanımlama biçimi ve ülkedeki azınlıkları yeri ve konumu açısından önemliydi. 2004 yılında Kazakistan Halk Meclisi, Kazakistan Cumhurbaşkanı Nursultan Nazarbayev tarafından "Milli Birlik Doktrini" ni ("Kazakistan Milleti") önerdi. Bu öneri, 120'den fazla etnik gruba sahip olan Kazakistan için tehlikeliydi. Kazakistan topraklarında etnik grupların söz sahibi olabilecekleri düşünülünce Kazak milliliğinden yana olanlar "Kazakistan Milleti” doktrine karşı çıktılar. Kazakistan Cumhuriyeti'nin sadece Kazakların bir devleti olduğunu iddia ettiler. Mesela, önde gelen Kazak siyasetçi, şair, aktivist, gazeteci Muhtar Şahanov "Ultty zhoyudyy tote zholy - Kazakhstandyk ult" (Bir ulusun yok edilmesinin doğrudan yolu - Kazakistan milletidir) diyerek konunun vahametini ortaya koydu (Aitymbetov vd., 2015: 2). "Kazakistan milleti” tanımlaması bağımsızlığın ilk yıllarında Kazakistan'ın etnik ve ekonomik durumu düşünüldüğünde doğru bir adımdı. Bu adımla birlikte Rusça'nın kullanıldığı alanlarda Kazak dilinin tanıtılması, Rusça kullanımının azaltılması veya ortadan kaldırılması, Kazak kültürü ve tarihinin yeniden değerli ve yaygın hâle getirilmesi gibi Kazak milliyetçiliğini öne çıkaran uygulamalar da görüldü (Aitymbetov vd., 2015: 6). Sadece dil ve kültür açısından değil millî para (tenge), millî marş'ın kabulü, millî kurumların oluşması etnik göçün dengelenmesi, yurt dışındaki Kazakların yurda dönmesi, çok çocuklu Kazak aile yapısının desteklenmesi Kazak millî kimliğinin şekillenmesinde ve millî kimlik bilincinin oluşmasında önemli adımlardı. Bu adımlarla Nazarbayev'in amacı, Kazakistan Cumhuriyeti'ni millî, çağdaş ve gelişmiş ülkeler seviyesine yükseltebilmekti.

\section{Sovyet Dönemi Kazak Kimliği}

Kazak kimliğinin farklı politika ve uygulamalarla baskı altına alındığı tarihî dönemeçlerden biri Sovyet dönemidir. Bu dönem, etnik kimliklerin ifade edilmesini yasaklarken diğer taraftan tarihî, dili ve kültürleri çarpıtmak adına bölgesel milliyetçi kimlikleri güçlendirerek kendine özgü bir milliyetçiliği de destekledi (Arsal, 2018: 10). Sovyet insanını ortaya çıkarmaya yönelik düzende amaç, sosyalist ve komünist ideolojiye sahip, ateizmin etkili olduğu itaatkâr insan topluluğuna erişmekti. Sovyet ulusu imajında diğer önemli nokta dildi. Kiril alfabesi ve Rus Dili resmîyet kazandı. Merkezî hükümet tarafindan 1921 yılında resmî yazışmaların Rus diliyle yapılması kararını çıkarıldı. 1938 yılında Kazak okullarında Rus Dili öğretilmesi zorunlu oldu. 1939 yılında ise Kiril alfabesi resmî olarak kabul edildi. Alfabelerin bu şekilde değiştirilmesindeki amaç, Kazakların kamusal alanda iletişim problemi yaşamasına, genç nesile Rusça öğretilmek suretiyle geçmişi ile bağlarının zayıflatılması ve dil yoluyla Ruslaştırılmasıydı (Kaya, 2012: 364-365). Bunun yanı sıra Sovyet Dönemi'ni yaşayan Kazaklar, kültür ve kimliklerine dair olumsuz uygulama ve bask1lardan 
söz ederken ekonomik ve sosyal hayattaki uygulamalardan memnuniyetlerini de ifade ettiler. Şöyle ki, eğitimin ve sağlı hizmetinin ücretsiz olması, iş bulma ve işe yerleşme imkânı, devlet tarafindan ekonomik anlamda uygulanan indirimler, maaşların zamanında ödenmesi, piyasadaki fiyatların devlet tarafindan belirlenmesi ve her yerde aynı olması olumlu hatıralardı. Kaynak kişilerin olumsuz olarak nitelendirdiği uygulamalar ise Rusça'nın konuşma zorunluluğu, inanç ve ibadet özgürlüğünün olmaması, ateist propagandanın yapılması, düşünce ve konuşma özgürlüğünün olmaması, kolektifleştirme ile özel mülkiyete el konulması, yurtdışına seyahat özgürlüğünün bulunmaması ise hafızalardaki derin olumsuz izlerdi (Ercilasun Kurmangaliyeva, 2019: 132-133). Bu baskılardan korunma yöntemi ise Kazak tarihçilerin ve bilim insanlarının Kazak kimliğine ve kültürüne dair yaptıkları uyarıların onları farkındalığını artırdı (Demirci, 2013: 289). Uyarılar farkındalıkları artırdığı gibi Kazak milliyetçiliğini ve kimlik şuurunu besledi.

Sovyet döneminde Kazak kimliği ve milliyetçiliğinin destekleyen Kazak aydınlarının yanı sıra Sovyet yönetiminde önemli Kazak lideri Dinmuhammed Kunayev'in iyi bir siyasetçi olması Kazakların milliyetçi yapılarını destekleyen diğer önemli bir durumdu. Sovyet Sosyalist Cumhuriyetler içerisinde Kunayev (1913-1993), 1960 yılında Kazak Birinci Parti Sekreterliği’ne getirilmesiyle siyasi durum diğer Türk Cumhuriyetlerine nazaran Kazakistan da güçlendi. Kunayev, Brejnev'in himayesinde Sovyetler Birliği Komünist Partisi'nin 1966'da Politbüro'nun aday üyesiydi, 1971'de tam üyesi oldu. Orta Asya Parti liderleri arasında tekti ve başarılıydı. Onun gücü ve etkisiyle Kazakistan 19601980 yılları arasında önemli ve güçlü cumhuriyetlerden biri oldu. Bu dönemde Kazakistan, Sovyetlerin yakıt ve güç merkezi, büyük ölçekli et ve tahıl üretim merkezi, nükleer cephanelik ve uzay araştırmalarının merkezi olmasıyla önemli bir konumdaydı. Diğer cumhuriyetler içerisinde Kazakistan'da etnik çeşitlilik fazla olmasına rağmen Kazaklar toplam nüfusun \%40'1nı temsil etti. Sovyetler, Kazakistanla "enternasyonalizmin" olağanüstü bir örneği olarak gurur duyuyordu (Akiner, 1995: 51-52). 1970’lerden itibaren Kunayev döneminde, Kazak somut kültürel mirasları olan Kazak yurtları (otağları), millı̂ motifler, el işlemeleri, kumaşlar, silahlar, Kazak halk müzikleri ve destanlar yoğun şekilde görülmeye başlandı (Akiner, 1995: 54-55). Gorbaçov'la millî kimlik konularında anlaşamayan Kunayev, görevi boyunca millî davaya bağlı çağdaş Kazak aydınlarına destek vererek onların gelişmesinde büyük rol oynadı (Gündoğdu vd., 2017: 78). Diğer taraftan, Kazakistan'da Kunayev'in ardından kurulan Nazarbayev yönetiminde de Sovyet kültür ve anlayışından farklı kendine özgü millî kültürü geliştirmek ve ortak kimliği oluşturmak temel amaçtı (Fragner, 2018: 32). 


\section{Nursultan Nazarbayev’in Liderlik Süreci}

Sovyet döneminde Kazak kimliğinin gerçek uyanışını sağlayan 1986 Aralık Almatı/ Jeltoksan olayları idi. Bu olayları Dinmuhammed Kunayev'in görevden alınarak Gennady Vasilevich Kolbin'in göreve getirilmesi tetikledi. Gorbaçov Kunayev'e gençlerle bir toplantı yapmasının yasak olduğunu söyledi. Kolbinle birlikte gençlerle konuşması için Mukashev, Kamalidenov, Nazarbayev'i üç üst düzey yetkiliyi görevlendirdi. Birlikte açıklama yapmak için kürsüye çıktılar ve grup sözcüsü olarak Nazarbayev, Kolbin'in atanmasını desteklediklerini söyledi. Gençler: "Biz hainlerle konuşmak istemiyoruz" diye bağırdı ve görevlendirilen kişileri kartopu ile vurmaya başladı. Kısa süre sonra 5-6 kişi Kolbin'le buluştu. Ancak buluşma ardından olaylar alevlendi, birçok gösterici yaralandı, tutuklandı ve cezalandırıldı. Göstericilerin üzerine tanklar gönderildi. Göstericilerin bir kısmı ağır yaralandı, bir kısmı tutuklandı ve hapse atıldı. Bağımsızlık öncesi bu olaylar, milliyetçi ve millî şuurun bir sonucu olarak ortaya çıktı. Diğer taraftan da 1989 yılında Sovyetler Birliği'nin batı cumhuriyetlerinde ortaya çıkan demokratikleşme sürecinin de Kazakistan'a yansımasıydı. Bu demokratikleşme süreci Nursultan Nazarbayev'in Birinci Parti Sekreteri görevine atanmasiyla hemen hemen aynı döneme rast geldi (Akiner,1995: 55-56).

1 Aralık 1991'de Kazakistan tarihinde ilk defa devlet başkanlığı seçimi yapılarak Nursultan Nazarbayev seçildi. Seçimlerden sonra, Kazak Parlamentosu aldığı bir kararla, ülke adından "Sovyet Sosyalist" ibaresini kaldırdı ve devletin resmî adını "Kazakistan Cumhuriyeti" yaptı (Kara, 2017a: 89). 16 Aralık 1991'de bağımsızlık açıklamasında, totaliter sosyalist sistemden parlamenter demokratik sisteme geçildiği duyuruldu. 20-21 Aralık 1991 tarihlerinde Almatı'da düzenlenen toplantıda Kazakistan'ın diğer yedi eski Sovyet cumhuriyeti ile birlikte Bağımsız Devletler Topluluğu'na kabul edilmesine karar verildi. 28 Ocak 1993 Anayasası'nda Kazakistan Cumhuriyeti'nin demokratik, laik ve üniter bir devlet olduğu belirtildi. 1993 Anayasası'nda Kazakistan'da yarı-başkanlık sistemi benimsenirken 1995 yılında düzenlenen anayasayla ülkede tam başkanlık sistemi kabul edildi. Cumhurbaşkanının yetkileri genişletilerek onun faaliyetlerini kısıtlayan Anayasa Mahkemesi kaldırıldı ve cumhurbaşkanlı̆̆ 1 süresi 5 yıldan 7 yıla çıkarıldı (Akiner, 1995: 60; Kara, 2017a: 81). 1991 y1lında devlet başkanı seçilen Nazarbayev'in 1995 yılında yapılan halk oylamasının neticesinde görev süresi 2000 yılına uzatıldı. Diğer Türk cumhuriyetlerinde olduğu gibi Kazakistan'da da Nazarbayev'in şahsında otoriter bir rejim kuruldu. Kazakistan cumhurbaşkanı, parlamentoyu feshedebilmekte, bir y1llık bir süreyle yasama görevini üstlenebilmekteydi (Kara, 2017a: s.83). 1995 y1lında düzenlenen Kazakistan Anayasasına göre, devlet başkanının Kazakçaya vakıf olması ve devlet başkanının resmî dil Kazakçayı iyi bilmesi şartı getirildi (Kara, 2017a: 80). Kazakistan Cumhuriyeti olarak devletin adının belirlenmesi, devlet başkanının Kazakça bilmesinin şart olarak koşulması, başkanlık sisteminin 
getirilerek yönetimin tek elden yürütülmesi ile millî kimliğin desteklenmesini sağlayan ilk dönemlerdi.

Bağımsız Kazakistan'ın varlı̆̆ını ifade eden semboller ve kurumlar ortaya çıktı, millî bayrak, millî marş, merkez bankası, Millî Savunma Kuvvetleri’nin kurulması sağlandı. Kazakistan Cumhuriyeti'nin millî sembolleri olan bayrak ve devlet arması 4 Haziran 1992 tarihinde; millî marş ise 11 Aralık 1992 tarihinde parlamento tarafindan kabul edildi. Cumhuriyetin ilk anayasası 28 Ocak 1993 onaylandı (Kara, 2017a: 93). Bağımsızlık sonrası dönemde eski Sovyet para birimi rublenin kullanılmasından kaynaklanan sorunları ortadan kaldırmak ve millî ekonomiyi güçlendirmek amacıyla, 15 Kasım 1993’te para birimi “tenge” tedavüle girdi (Akiner, 1995: 61; Kara, 2017a: 82).

Siyasi mânada millî devletin kurulması gerçekleşirken sosyokültürel faaliyetlere de ağırlık verildi. Büyük imar faaliyetlerine girişildi. Kozmopolit halk yapısına sahip olan Kazakistan, Kazakistan'ın kuzey merkezindeki İşim nehri üzerindeki Akmola, 20 Ekim 1997'de Kazakistan Cumhuriyeti'nin stratejik önem kazanması, istikrarlı ve etkili ulaşımı için Almatı'dan sonra yeni başkenti oldu. 6 Mayıs 1998'de Akmola şehrinin ad “'Astana” olarak değiştirildi (Schartz, 2000: 492; Kara, 2017a: 93-94). Astana şehrinin ad1 23 Mart 2019 tarihinde NurSultan olarak kabul edildi.

\section{Milliyetçilik ve Millî Kimlik Noktasında Kazakistan'ın Kültürel Dinamikleri}

Sadri Maksudî Arsal, milliyet duygusunun milletlerin uzun tarihlerinin bir sonucu olduğunu, milliyet duygusunun kuvvet ve derinliğinin tarihleri ile millî kültür bilgisine bağlı olduğunu; tarihlerine ve kültür eserlerini unuturlarsa milliyet şuurunu kaybederek milletleşmekten uzaklaşacaklarını ifade etti (Arsal, 2018: 211). Bağımsız bir devlet olabilmek ise belirli bir coğrafya, ortak bir kültürün bulunması gerekmekteydi. Kazakistan Cumhuriyeti, coğrafya ve millî kültür noktasında tarihten gelen önemli bir geçmişe sahipti. Bağımsızlıklarının öncesinde kendi kültürleri, tarihleri ve belli kimlikleri olan topluluklardı yani birdenbire ortaya çıkmış topluluklar değillerdi. Nursultan Nazarbayev'in sözleriyle Her ailenin kendi evini kurma hayali vardır. Her şey bu basit fikirle başlar. Özellikle yaşlı kuşaklardan pek çok insan, iyi bir ev inşa etmenin ne kadar zor olduğunu iyi bilir. Genç bir devleti, ortak evimiz Kazakistan'ı kurmanın bundan da zor olacağını tahmin edersiniz ve Kazakistan, temellerine konan her bir taşı bilmek zorundadır (Nazarbayev, 2012b:7). Tarihi süreç ve emeğin bir sonucu olarak Kazakistan Cumhuriyeti'ni ortaya çıkardığı açıktı. 
Tarihî süreçle şekillenen millî kimlik, belli insan topluluğuna aidiyet duygusu vererek kendilerini ifade eden ortak kültürlerine bağlllıklarını ifade eder. Bu noktada Nazarbayev, Kazakların millî kimliğinin belirlenmesinde kendi devlet yapısına kavuşmasının sebebini şöyle dile getirdi: Tüm baskılara ve bozulmalara rağmen Kazaklar yirminci yüzyllın başına kadar geleneksel yaşam tarzının (göçebelik) muhafaza ederek aynı coğrafyada diğer halklarla ylğınsal olarak karışmamalarıyla öz benliklerini korudular. Bunun yanı sıra kimliğin korunmasında Kazakistan'in genç nüfusa sahip olmasının onları güçlendiren diğer bir faktördü (Nazarbayev, 2012a: 23-24). Kazakistan coğrafyasında kimliğin oluşumunu destekleyen ata toprakları, tarihî ve kültürleri ve nüfus yoğunluğu etkili oldu. Böylece 1990'larda Brubaker'ın söylediği gibi sosyalist sonrası dönem 'millileştirilmiş devletleri' ortaya çıkardı. Devletin dil kullanım kalıplarını şekillendirme, tarihleri yeniden yazma, demografik dengeleri değiştirme ve etnik kadroları teşvik etme çabaları, artık etnik kökenin bölgede baskın siyasi aynı zamanda millî kimlik doğal görünmeye başladı (Schartz, 2000: 490).

Kazak kültürü, Türk kültürünün temelini oluşturan bozkır göçebe yaşamının biçimlendirdiği bütünleyici bir düşünce tarzından beslendi. Göçebe kültürü sonraki dönemde yerini yerleşik hayata bırakmış olsa da hâlen kültürel kodlarda göçebe anlayışın devam ettiği görülür. Bu noktada, aileyi ifade eden otağları, dastarhanları, boy anlayışları, yedi ata geleneği, aile ve akrabalık ilişkileri, misafirperverlik özellikleri nesilden nesile aktarılan bir miras olarak günümüze kadar geldi. Göçebe mirası ve geleneklere bağlılık hem Kazaklar arasında hem de yerleşik komşularından daha güçlü etnik köken ve geleneklerine bağl1lı duygusunu ortaya çıkardı. Göçebe mirası özelliklerinin vurgulanması, Sovyetlerin uygulamalarıyla gelişen kültürdeki köksüzlük ve yabancılaşma duygusunu azaltmaya ve Kazakların özgüvenini geliştirmeye yardımcı oldu (Akiner,1995: 66). Göçebe mirasının vurgulanmasının bir başka nedeni, İslami geleneğe karşı bir denge oluşturmaktı. Nazarbayev, günümüz Kazakistan toplumunun kökten dinci fikirlerden etkilenmemeleri için göçebe kültürel miraslarına sahip çıkıldığı ve göçebe kültüründen dolayı kökten dinici fikirlerden etkilenmeyecekleri vurgulandı (Akiner, 1995: 67). Sovyetler döneminde bu topraklar, Türklüklerinden ziyade Müslüman olarak görüldü, Komünist Partisi etkisini güçlendirme sorununu "Müslüman sorunu" nun üstesinden gelme olarak gördü ve politik ve stratejik bir değer haline getirerek değerlendirdi. 1928' de Sovyet yetkilileri İslamî okullarının (mektep-medrese) tamamını kapattı (Wimbush, 1986: 1-4). Nazarbayev ise köktendinciliğe karşı dururken İslâm, milli kültürün canlandırılmasında manevi dirilişte önemli itici bir güç olarak gördü (Nazarbayev, 2012a: 77). Nitekim Nazarbayev, İslam'1 resmî din olarak kabul ettiklerini ve bundan gurur duyduklarını ancak Müslümanlığı kullanarak bir yerlere gelemeyeceklerini ifade etti. Ayrıca "Diğer İslam devletlerine ve 
İslamı yaşama biçimlerine saygımız sonsuz. Fakat biz Arap değiliz, biz göçebe ve Türk'üz." diyerek İslam'a bakış açısını ortaya koydu (Bayer, 2014).

Kazak tarihinde Kazak milliyetçiliğini ve Türklük bilincini besleyen tarihî dört önemli olay bulunur. Bunlar, Alaş Orda Millî Hükümeti (1917-1920), Din Muhammed Kunayev (1960-1980) dönemi, 1986 Aralık Almatı/ Jeltoksan olayları, bağımsızlık sonrası dönemde Nazarbayev'in yasa ve uygulamalarıydı. İlk olarak Alaş Orda Hareketi ve ardından kurulan hükümetle Kazak kimliğinin belirleyiciliğin de Türklük anlayışı göze çarptı. Türkçü anlayış, özellikle Alaş Orda hareketinin üyeleri arasında, 20. yüzyılın başlarında önem kazandı. Alaş Orda Hareketi, Türkçü ve bir dereceye kadar da İslami anlayışı kabul etti; bu bağlar yıldız ve hilal, kurt başı gibi simgelerle ifade edildi. Bu hareket 1980'lerde yeniden milliyetçi ruh ile ortaya çıktı 1986 Almatı olayları ve ardından bağımsızlıkla Türklük bağları, ortak bir Türk kültürünün varlığı, Türkiye'de eğitim bursları ve Kazakça-Türkçe sözlüklerin derlenmesiyle güçlendirildi. Bunun yanı sıra, Nazarbayev'in desteğiyle piyasa ekonomisinin bir örneği olan Türkiye'ye odaklanılmasına karar verildi. 1995 yılında Bişkek'te Türk Cumhuriyetleri arasında düzenlenen toplantıda liderler tarafindan "Türklerin kardeşliği" söylemi kullanılarak Türklerin ortak çıkarları ve ortak bilincin oluşmasına dair çalışmaların yapılmasına karar verildi (Akiner, 1995: 66-67).

Kazakların millî kimliklerini güçlendiren diğer önemli özelliklerinden biri de vatanlarına duydukları tutkulu bağdı. Kazaklar tarihî devirlerden itibaren hemen hemen aynı coğrafya da bulunmalarından dolayı hem sembolik hem de fiziksel bir bağlanma oluşturmaları mümkündü. Kazak dilinde anavatanı tanımlamak için atameken, atajurt, otan ve tarikhi otan kavramlarına yer verildi. Bu kavramlar tarihî kökeni ifade ettiği gibi Kazak ulusunun Kazak topraklarındaki varlığına da vurguladı (Kuşcu, 2012: 181). Kazakların atalarının toprakları olan bu coğrafya onların tarihî bağlarından kopmamalarını sağladı. Bu sebepten Sovyet döneminde "Sovyet Mühendisliği" ortaya çıkarılarak yeni bir Sovyet insanı oluşturma uygulamalarının başarısızlığa uğrama sebeplerinden biri coğrafya ile kurdukları güçlü vatan sevgisidir.

Bağımsızlık kazanımlarını yeniden anlamlandırmak için millî kimliğin yenilenmesi kaçınılmazdı. Kazak kültürüne ilişkin geleneksel değer yargıları, Kazak Cumhuriyeti'nin meşruiyeti gibi kabul edilen siyasi anlayışın şekillenmesine dair varsayımlar sorgulandı. Sovyet baskısının aniden ortadan kaldırılmasıyla Kazaklar arasında "Kazaklık" ne demekti, hangi özellikleri taşıdığına dair tartışmalar başladı. Bağımsızlık sonrası "Kazaklık" özelliklerini besleyecek ve Ruslardan koparacak önemli tarihî amaç vardı. Bunlardan ilki Kazak Hanlığı ile bağlar güçlendirilerek Rus işgali öncesinde toprak sınırlarına dair bir meşruiyet oluşturmak için tarihî kökleri benimsemek; diğeri ise Sovyet Dönemi’nin Kazak halkına uyguladığı politikalarla sosyokültürel alanda oluşan 
geçmiş ile bugün arasındaki derin kopukluğu kapatmaktı. Bu amaçlarla, 1995 yılında Kazak Hanlığının kuruluşunun 540. Kuruluş yılı kutlandı, köklere bağl11ık vurguland1 (Akiner, 1995: 62). Alihan Bökeyhanov, Ahmet Baytursinov, Mırjakıp Dulatov, Jakıp Akpayev, Muhamedjan Tınışpayve, Bahıtjan Karatyev, Mustafa Çokay, Hâlel Dosmuhamedov, Magcan Cumabayev, Abay Kunanbay, Abılay Han gibi tarihsel ve Kazak aydınlarına öncelik verilerek Kazaklık ruhu canlandırıldı (Nazarbayev, 2012a: 127).

\section{Nursultan Nazarbayev'in Milliyetçiliği}

Sovyetler Birliği'nin çöküşü, Sovyet sonrası Orta Asya'da yeni ulusdevletlerin kurulmasına yol açtı. Sadri Maksudî Arsal'ın ifadesiyle millî his ve şuuru kuvvetli olan milletler, millî ve siyasi bağımsızlıklarını kaybettikten uzun zaman sonra bile yüzyıllarca yabancı milletlerin boyunduruğu altında kaldıktan sonra bile milliyetlerini unutmazlar, millî şuurlarını kaybetmezler. Bazıları dillerini unutsalar da millî ruhlarını, millî karakterlerini, dinlerini korumaya alırlar ve bu sayede millî istiklallerini yeniden elde ederler (Arsal, 2018: 211212). Bununla birlikte, bağımsızlığın ardından etnik-demografik durum göz önüne alındığında Kazak nüfusunda yaklaşık\% 40,1'i oluşturduğu için Kazakistan'ın yöneticileri tamamen etnik milliyetçilik uygulayamadı (Kesici, 2011: 31). Kazaklara kimlikleri sorulduğunda cüz ve ru'larını söyleyerek cevap verirler. Nazarbayev, Kazakistan'da bulunan boy birlikleri içerisinde yedi ata (şecere geleneği) geleneğinin onları geniş coğrafyada ve yabanc1 hâkimiyetler altında yok olmalarını engellediğini ifade etti. Çocukların yetişme çağında soyunu, boyunu, atalarını, yedi kuşağını (jeti ata) öğretilmesi kimlik bilincine varmalarında önemli olarak görüldü (Nazarbayev, 2012a: 33-41). Kazaklığın etnik göstergelerinden cüz ve ru temelinde şecere anlayışında ulus inşası, Slav ve diğer etnik gruplardan ayıran önemli bir özellik ve alt kimlikleri bütünleştiren araçlard1 (Schartz, 2000: 498; Çetin, 2014: 19). Bu şecere geleneği, bir sosyal birlikteliği (akraba- tanıdık) ifade ettiği gibi millî ve etnik unsurlarını da barındırdı. Bunun yanı sıra, Kazakistan'ı bir arada tutabilmek adına Nazarbayev, 2010 yılında halka açık konuşmasında "Millî Birlik Doktrini”ni açıkladı. Nazarbayev bu doktrinde tüm etnik grupların ortak kaderini ve tarihini bir kez daha vurgulayarak "Bir toprak, bir kader" olarak tanımladı. Doktrinin ikinci ilkesi, "farklı kökenlere eşitlik", üçüncü ilkesi ise "millî ruhun gelişimi”ydi. Bu ruhun gelişimini ise vatanseverlik, rekabet ve başarı olarak gösterdi (Kesici, 2011: 53).

Nazarbayev'in millî kimlik ve kültürün güçlendirilmesi adına milliyetçi politikalardan en önemlisi yurtdışında yaşayan Kazaklarla kurulan ilişkilerdi. Kazakların dış ülkelerden göçü, Kazak kültürü ve geleneklerin canlandırılmasında da önemli etkiye sahip oldu. Kazakistan'ın bağımsızlığını elde etmesi ardından yurtiçi ve yurtdışındaki Kazakların buluşturulmasına 
öncelik verildi. İlk defa 1991 'de gerçekleşen buluşmada dünyanın dört bir yanından gelen Kazaklara cumhuriyetlerine sahip çıkarak yerleşmelerini istendi. Nazarbayev, bu yurt dışındaki Kazaklar ile ülkedeki Kazakların iletişimlerinin güçlendirmesini "altın köprü" olarak tanımladı (Akiner, 1995: 68; Colleen, 2019; Kuşcu, 2012: 184). Resmî politika tasarısı etnik Rusları Kazakistan'dan uzaklaştırmak olmasa da bu şekilde sonuçlandı. 1993- 1998 yılları arasında 815. 237 Rus göç etti. Kazaklar arasında nispeten yüksek doğum oranları, göçmen Kazakların yurtdışından anavatana dönmeleri Kazak nüfusunun 1989'dan 1995'e kadar\% 16,8'lik şeklinde büyümesine yol açarken Rus nüfusu \% 7.4 oranında küçüldü. Cumhuriyet genelindeki 1999 nüfus sayımının ilk sonuçları, Kazakların nüfusun\% 53,4'ünü oluşturduğunu gösterdi (Schartz, 2000: 496).

Yurtdışında yaşayan Kazaklarla bağlantı iki şekilde sağlandı. Öncelikli olarak yurt dışında yaşayan Kazakların ulusal karakteristik özelliğini, ana dili, gelenek ve göreneklerini, kültürel değerlerini korumaları için yaşadıkları bölgelerde destek verildi. Ayrıca, Kazakistan'a kesin dönüş yapanlardan ülkenin sosyal ve ekonomik, kültürel ve manevi açıdan gelenek ve göreneklerin yeniden canlandırılmasına katkıda bulunmaları istendi. Bunun yanı sıra yurtdışındaki Kazakların çok çocuklu aileye sahip olmalarından dolayı az nüfuslu Kazakistan'ın demografik yapısının değişmesine ve etnik nüfus artışına katkı sağlayacağı düşünüldü. Yurtdışından gelen Kazaklar, nüfus artış hızı düşük ve verimli bölgelere yerleştirme planı yapıldı. Mesela, Özbekistan'da tarım kültürünün yeterince gelişmiş olmasından dolayı Kazakların bu kültürü benimsemesi istendi. Çin'de yaşayan Kazakların ise tarım makineleri, araçgereçler konusunda uzmanlaştıkları için Kazakistan'1 geliştireceği düşünüldü. Diğer taraftan hayvancılığın yeniden canlandırılması için Doğu Türkistan ve Moğolistan'da yaşayan Kazakların Kazakistan'a gelerek hayvancılı̆̆ 1 geliştireceği ön görüldü (Nazarbayev, 2017: 13-14). 2003 yılında yurt dışındaki Kazaklarla yapılan ikinci toplantıda Kazakların ülkelerine dönmelerinden duyduğu heyecanı anlattı. Aynı konuşmada, ülkeye dönen göçmenlerin karşılaşacağ 1 zorluklardan bahsederek onlardan devletin kendileri için her şeyi yapmalarını beklememelerini, 2005 yılında yapılan Üçüncü Kurultay'da ise "Anavatana göç eden kardeşimiz ana vatanın kendine ne vereceğini değil Kazakistan'a kendilerinin ne vereceğini düşünmelerini" isteyerek gerçekçi bir üslup kullandı (Kuşcu, 2012: 183). Nazarbayev ayrıca, yurtdışında yaşayan Kazakların Kazakça eğitim alamadıklarını, bu sebepten Kazak çocuklarının yabancı dilde eğitim aldıklarını, ana dillerini bilmediklerini ifade ederek bu konuda çalışmaların yapılmasını istedi (Nazarbayev, 2017: 20).

1995 yılında danışma ve istişare amaçlı Kazakistan Halklar Asamblesi kuruldu. Bu kurum, parlamentoya dokuz milletvekili seçme hakkını elde etti, seçilen milletvekilleri ise tüm etnik azınlıkları temsil ederek çıkarlarını koruma hakk1 elde etti (Osmanova, 2019: 3). Nazarbayev, halklar kurumu yargı, yürütme 
gibi güçlerden yoksun, siyasi etkinliği olamayan bir yapılanmaydı. Bu kurum, etnik azınlık temsilcilerine verilen Kazakistan'a bağlılık nişanıydı. Bu kurum, azınlıkların taleplerinin ve hareketlerinin kontrol edilmesinde önemli bir araçtı. Azınlıkların Kazak devletine hizmet ettiği, hükümete ve kendine bağlı bir azınlık topluluğu oluşturmak istedi (Çetin, 2014, 24).

Bağımsızlık sonrası devlet Kazak kültürünü teşvik etmek için çeşitli uygulamaları ortaya koydu. Özellikle 1990'ların ilk yarısında, gazeteler millî gelenek ve göreneklerin aktarımına geniş yer verdi. Başkan Nazarbayev, Tarih ve Etnografya Enstitüsü ile araştırmacılara Saka dönemine ait Kazak devletinin köklerini (MÖ ilk binyıl) bulma görevini verdi. Böylece, Kazak tarihinin XV. yüzyılın ortalarında Kazak Hanlığının kuruluşundan çok daha erken devirlerde başladığı gösterilmek istendi. Bazen de araştırmacılar, etnik sahiplenmeyi tasvir etmek için Cengiz Han'ı ve onun Avrasya imparatorluğunu Kazak olarak benimsetmeyi Kazakların alternatif tarihî olarak görür. Bir diğer iddia ise XVI. yüzyılın ikinci yarısında Sibirya Hanlığının Han'ı olan Küçüm Han'ın Kazak olduğu ifade edildi. Kazak tarihinde önemli rol oynamış tarihsel şahsiyetlerin benimsetilmesi için çeşitli mimari anıtlar yapıldı veya restore edildi (Schartz, 2000: 496). Nazarbayev tarafından 2000 yılında bilim insanlarının millî tarih ve kültür çalışmalarına ağırlık verilmesini desteklemek amaçlı "Kültürel Miras Programı" başlatıldı (Kara, 2017a: 99). Bu durum, Türkiye Cumhuriyeti’nin kuruluş aşamasında Türk Tarih Kurumu'nun kurulması (1931) ve Türklerin Dünya tarihine ve medeniyetine yaptıkları katkıları araştırmaları üzerine çalışmalar ve toplantılar yapılmasıyla benzer özellikler gösterir.

Millî bilinçlenme noktasında tarihte yer almış Kazak aydınları Alihan Bökeyhanov, Ahmet Baytursınov, Mırcakıp Dulatov, Mustafa Şokay, Hâlel Dosmuhamedov, Magcan Cumabayev'in eserleri yayınlanarak bu kişilerin anılmasına yönelik programlar geliştirildi. Kazakistan'da millî görüş ve düşünceler, Türk'ün ortak atası, Türk Dünyası, Türk medeniyeti, Türk ortak mirası, Kazak ulusu, anayurt, atayurt, vatan, millî dil, millî şuur, millî ülkü, millî düşünce, millî örf, millî töre, millî kültür, millî edebiyat, millî sanat gibi kavramlarla öne çıkarıldı (Abdirassilova vd., 2017: 13-14). Kazakistan'da Sovyet ve Komünist sembolik gereçleri tarih yazımıyla değiştirilerek halk efsaneleri ve halk kahramanları (Baturlar) ön plana çıkarıldı. Kazakistan toprakları üzerinde önemli merkezlere Lenin ve Stalin heykelleri yerini Cengiz Han ve Timur heykellerine biraktı. Nazarbayev tarafindan yeni hükümetin ideolojik omurgası halîne gelen büyüyen bir milliyetçiliği destekledi (Joldoshov, 2019: 304).

Nazarbayev'in 2003 yılındaki kararnamesiyle, Kazakistan kültürel mirasını incelemek, kültürel, tarihî eserleri yeniden inşa etmek, Kazak edebiyatını korumak, kültürel ve arkeolojik araştırmalar yapmak kararı alındı. 2004 yılında “Madeni Mura Projesi”yle Kazakistan'ın kültürel ve manevi mirasını ortaya 
çıkarma, kültürel simge yapılarının tamiri ve korunması amaçlandı. 2013 yılında "Khalyk tarikh tolkynynda" (Halk Tarihin Akışında) programı ile dünyanın önde gelen arşivlerinden Kazakların tarihinde önem rol oynamış kişi ve simgelerin araştırılması karar verildi. Bu program ile modernleşmenin millî kültür ve geleneklere bağl1lıkla kendi kültürlerinden kopmadan günümüze uyarlanması hedeflendi. Nazarbayev modernizmi, Başarılı bir modernizasyon için ilk koşul, ulusal kültür ve geleneğin korunmasıdır. Millî kültür ve gelenek olmadan modernleşme boş bir retoriktir, ancak ulusal kültürdeki her şeyin korunmast anlamina da gelmemektedir. Gelecekte bize güven veren ve bizi geride tutan unsurları ayırmamı gerekiyor. Modernleşme, millî ve kültürel kökler olmadan havada asılı kalacaktır, ben sağlam durmasını istiyorum. Tarih ve millî kültür dikkate alınmalıdır. Manevî modernleşmenin en önemli misyonunun millî kültür anlayışımızla uzlaştırmak olduğuna inanıyorum. dedi (https://100kitap.kz/kz/president-articlel, 12.03.2020).

Birinci Cumhurbaşkanı Nursultan Nazarbayev, "Geleceğe yol: Manevi Yenilenme" başl1klı makalesinde, Kazak toplumunun sadece mühendislere ve doktorlara değil, aynı zamanda insani alandaki modern zamanı ve geleceği derinden etkileyecek profesyonellere de ihtiyacı olduğunu belirtti. Bu bağlamda, öğrencilerin tarih, siyaset bilimi, sosyoloji ve felsefe, psikoloji, pedagoji, ekonomi, kültür bilimi ve filolojisinde zamanın gereksinimlerini karşılayan bir eğitim almalarını istedi. Bu konuda ülkenin çalışmalar yapması için kurumun başkanlığına Rauan Kenzhekhanuly getirildi. İngiltere, İspanya, Fransa, Rusya, Çin, Mısır ve Orta Doğu ülkelerinden baskı evleri, edebiyat eleştirmenleri, antoloji yazarları, çevirmenler, tercümanlardan oluşan bir grup oluşturuldu. Cumhurbaşkanlığı İdaresi İç Politikaları Dairesi Başkanı ve Ulusal Komisyon Sekreteri Rukhani Zhangyru ve Aida Balayeva, seçilmiş altmış Kazak yazarının eserlerinin altı Birleşmiş Milletler diline (İngilizce, Fransızca, Çince, Rusça, İspanyolca ve Arapça) çevrilmesi ve beş kıtada doksan ülkenin kütüphanelerine ve bilimsel merkezlerine ulaştırılması sağlanacaktı. Aida Balayeva, bu proje başarıyla sonuçlandığında 2.6 milyar insanın Kazak edebiyat şaheserlerine erişimi sağlanacağından Kazak eserler uluslar arası alanda temsil edileceğini ifade etti. Proje Kazakistan Cumhuriyeti Kültür ve Spor Bakanlığı tarafından görevlendirilen Ulusal Tercüme Bürosu tarafından uygulandı (https://100kitap.kz/en/event/21 , 12.03.2020). Rukhani Zhangyru projesinde, yüz yeni ders kitabı ile yeni kuşakların bilgiyle donanması ve yeni nesil Kazakistan halkının yetişmesi amaçlandı (https://ruh.kz/ru/latyn/,15.02.2020).

Nazarbayev döneminde "milliyetçilik" ideolojisi kapsamında Kazakistan'ın dine karşı duruşu da önemliydi. Yönetim bir taraftan Kazakların tanımlanmasında kullanılan değerler içerisinde İslamın ülkede gelişmesini isterken diğer taraftan seküler bir yönetim anlayışı benimsendi. Kazakistan'da diğer Türk Cumhuriyetlerinde olduğu gibi yönetimin laik yapısını korumak adına 1993 ve 
1995 Anayasalarında ülkenin laik bir ülke olduğunu vurgulandı. Laiklik ilkesiyle sadece din ve devlet işlerinin ayrılması olarak görülmedi; din-vicdan hürriyeti, diğer dinlere karşı hoşgörü, aynı zamanda aşırı dincilikle "kökten dincilik"le mücadele edileceğini ifade edildi. Laiklik ilkesiyle, Nazarbayev tarafindan Kazakların yüzyıllardır İslama inandığı, Sovyetlerin ateizm propagandasıyla halkın inancını kırmaya çalıştığ 1 ancak İslamın gücü ve eski kuşakların manevi sağlamlığıyla bu girişimlerin boşa çıktı̆̆ ifade edildi (Nazarbayev, 2012c: 79). Kazakistan'ın demografik yapısından kaynaklanan dinî çeşitliliğin problem olmaması için laiklik ilkesine önem verdiği görülür. Sadece kanunlarla değil, bu amaçla ilmî ve dinî müesseseler kurdu. Ekim 2011'de "Din İşleri Ajansı" kuruldu. $\mathrm{Bu}$ ajansla cumhuriyetin laiklik ilkesi gereği kamusal alanın dışına taşındı. Devlet, İslamın yanısıra Ortodoks Hristiyanlığı ve diğer bütün dinî yapılanmalarının kayıt ve kontrol edilmesini sağladı. Bunun yanında devlet kurumlarında, okullarda İslami usullere göre giyinmeyi, ibadet etmeyi ve dolayısıyla namaz kılmayı yasakladı. Ayrıca, Kazakistan'da Rus nüfusunun yoğun bulunduğu Akmola, Kostanai, Turgay ve Karaganda gibi şehirlerinde İslami faaliyetlere ağılık verilmesine karar verildi (Çetin, 2014: 46; Akiner, 1995: 64-66). Nazarbayev'in amacı, İslamın halk içerisinde desteklerken onun zararl1 hale gelmesini engellemek, ateizmin inanç ve siyasi sisteminden kurtulmak, aynı zaman çağdaş devletlere ayak uydurmaktı.

Türkistan coğrafyasında iki farklı İslam anlayışı bulunur. Bu iki İslamî anlayış farkı mezhepten değil yaşam tarzından kaynaklandı. Burada göçebe yaşam tarzını uzun süre koruyan Kazak, Kırgız, Türkmen gibi topluluklar ile yerleşik topluluklar olan Özbek ve Taciklerin islamı farklı anlamlandırmalarına bağlıydı. Yerleşik topluluklar İslam'ın öncüleri oldu ve bilimden edebiyata, tefsirden İslam hukukuna dinî geliştirmeye ve yaymaya çalışan topluluklar olarak ön plana çıktı. Bağımsızlığın kazanılmasından sonra Kazakistan'da İslam önemli bir yaşam sahası kazandı. Kazaklar kendilerini Ruslar ve diğer Slav halklarından ayırmak için İslamı araçsallaştırdı. İlk icraatlarından biri 1992'de Kur'an-1 Kerim Kazakçaya çevrildi. İslamın desteklenmesi noktasında 2009 yılında, ülkenin \%70'lik nüfusunun yaklaşık 11 milyon Müslüman'ın yaşadığı görüldü. Sovyet döneminden sonra cami 40'lardan 2300'lü sayılara yükseldi (Çetin, 2014: 42-45).

Emir Timur'un, Ebul Gazi'nin ve Hoca Ahmet Yesevi türbelerinin restorasyonuna önem verildi. Türkistan şehri hem tarihî hem de manevî açıdan Hoca Ahmet Yesevi'nin türbesinin bulunmasından dolayı restorasyonuna öncelik verildi. 2000 yılında Kazak tarihindeki Hoca Ahmet Yesevi türbesinin yapımı, Türkiye'den gelen maddi desteklerle 2000 yılında tamamlandı. Nazarbayev, 19 Haziran 2018 tarihinde Güney Kazakistan Eyaletinin adı Türkistan olarak değiştirildi. Eyalet merkezinin Çimkent'ten Türkistan'a taşınmasına iliş̧in “Kazakistan'ın İdari ve Bölgesel Yapılanma"sına yer veren kararnameyi imzaladı 


\section{H.Demirci Ilk Dönem Kazakistan Cumhuriveti’nde Milliyetcilik...}

(Raimbekova, 2018). Bu kararname, "manevi yenilenme" programının bir sonucuydu.

Kazakistan'da milliyetçilik ve millî kimliğin güçlendirilmesi noktasında uygulamalardan biri dil politikasıdır. Kazaklar arasında Kazakça bilmeyenlerin oranı 1989 nüfus sayımında \%40'lardadır. Genel nüfus içerisinde Kazakçayı bilmeyen Kazakların oranı ise yaklaşık \%25tir. Ayrıca, özellikle büyük şehirlerde yaşayanların büyük kısmı Rusçayı akıcı şekilde konuşmaktadır (Çetin, 2014: 37). Bağımsızlıktan önce 1989 yılında Kazakça devlet dili olarak kabul edildi. 1989 kanunuyla Kazak dili garanti altına alındı ve okullarda okutulması zorunlu hale geldi. 1940'lı yıllardan itibaren Rusça'nın baskın hale gelmeye başlamasıyla zayıflatılan Kazakça, yeniden canlandırılmaya çalışıldı. 1993 Anayasasında Kazakçaya tek resmî dil statüsü verildi. Rusça farklı etnik gruplar arasında iletişim dili olarak benimsendi. Bu durum, Kazakistan'da yaşayan etnik Rusların bu durumdan tedirgin olmasıla yapılan referandumla 1995 Eylül Anayasası'na göre Kazakça devlet dili olarak kabul edildi, Rusçaya ise resmî dil statüsü verildi. Yönetim ve idarede Kazakça ve Rusça eşit şekilde kullanılabileceği vurgulandı (Çetin, 2014, 38). 1995 Anayasası, Rusçayı 1993 Anayasasına göre daha yüksek bir noktaya taşımakla beraber Kazakça'nın güçlendirilme çalışmaları yapıldı. Kazakistan anayasasına göre, devlet dili Kazakçayı bilmeyen bir kişinin resmî görev alması engellendi. Diğer taraftan, başlangıçtan üniversiteye kadar yapılan mezuniyet sınavlarında öğrencinin Kazakça sınavlardan başarılı olma şartı konuldu. Resmî istatistiklere göre, tek dilli Kazak-ortaokulların sayısı 1989-96 yılları arasında yaklaşı \% $\% 28$ artarken, Rus-ortaokulların sayısı aynı dönemde yaklaşık \%37 azaldı. 2010 Kazakistan Anayasasında Kazakça bilmeyenlerin devlette çalışamayacağına dair madde eklendi, ancak daha sonra kaldırıldı (Çetin, 2014: 40). Ancak bu uygulamalar önemli olumsuz sonuçlar da doğurdu. Kazak dilinde uzmanların azlığı sebebiyle eğitim kalitesi düştü. Devlet kurumlarının Kazak dilinde eğitimi desteklemesiyle Kazak olmayanlar genellikle alternatif özel eğitim kurumlarına yöneldiler. Kazak dili medyası desteklendi, ancak Devlet Dil Geliştirme Bölümü Müdürü Erbol Shaimerdenov, röportajda Kazakça medya gazetelerine olan talebin eksikliğine değindi. 1999 yllında, televizyon yayınlarının\%50'sinin Kazakça yapılmasına ilişkin yasal zorunluluğun uygulanması ağırlıklı olarak Güney Kazakistan Bölgesi'nde kabul edildi. Ancak Kazakçanın yaygınlaştırılmasına yönelik politikalar kısa sürede istenilen verimliliğe ulaşmadı (Schartz, 2000: 494). İstenilen verimin alınması için yönetim yeni uygulamalara ağırlık verdi. Bu uygulamalar, dil devrimini destekler şekildeydi. Devlet Başkanı Nazarbayev tarafından 2007 yılında Kazakistan'da "Üçlü Dil Politikası" Rusça, İngilizce ve Kazakçayı kapsadı, üç dili bilen bir gençliğin yetiştirilmesi hedeflendi. Gençlerin öz dili ile millî köklerine dair eğitim yeniden canlandırıldı. Rusça ile geçmiş yılların bilgi birikiminden kopmamak İngilizce ile de dünya ile iletişim içerisinde olmak istendi (Çetin, 2014: 40). 
Kazakistan Cumhurbaşkanı Nursultan Nazarbayev 12 Nisan 2017'de Egemen Kazakistan gazetesinde yayınlanan "Geleceğe Yol: Manevi Yenilenme" başlıklı makalesinde, değişen dünyada Kazak halkının millî değerlerinin özünü değiştirmeden değişime ayak uydurması gerektiği ifade etti. Ayrıca makalede, Nazarbayev, Latin alfabesine geçişin derin bir mantığı olduğunu, günümüzün teknolojik iletişim ve 21. yüzyıl eğitiminin ortak alfabesi olduğunu söyledi. Nazarbayev, Türk okullarında çocukların İngilizce öğrenmekle Latin harflerini de öğrendiğini dolayısıyla gelecek kuşaklar için problem olmayacağını da ifade etti. Latin alfabesine iki yıl içerisinde geçme gerekliliğini vurguladı. Latin harflerine geçişte Kazakistan' da Cumhurbaşkanı Kararnamesi ile 26 Ekim 2017 tarihinde onaylandı. 2018 yılından itibaren yeni alfabeyi öğreten uzmanları ve okullara yönelik ders kitapları hazırlandı. Yeni alfabeye alışma sürecinde belli bir süre Kiril alfabesinin kullanılmasının ve 2025 yılında tamamıla Latin alfabesine geçilmesi ön görüldü (Kara, 2017b: 27; https://ruh.kz/ru/latyn/, 2020). Aslında Latin alfabesi ile Rusya ile tarihî sembolik bir kopuş daha gerçekleştirilmek istendi.

Nazarbayev, Kazakistan'da millî eğitim sistemi kurulması ve geliştirilmesinde de önemli etkiye sahip oldu. Kazakistan'ın en büyük eğitim projesi devlet destekli "Bolaşak Bursları" 5 Kasım 1993 tarihinde imzalanan kararname ile yürürlüğe konuldu. Bu burslar ile Kazakistanlı öğrencilerin dünyanın önde gelen yabancı üniversitelerinde eğitim almasını sağlanarak ülke yöneticilerinin, ülkenin ihtiyacı olan kalifiyeli insanların ve bilim insanlarının yetişmesi amaçlandı. Kazakistan Cumhuriyeti, kişi başına düşen üniversite kurumunda dünyanın önde gelen gelişmiş devletlerini geride bıraktı. Bu anlamda Nazarbayev Liseleri ve Nazarbayev Üniversiteleri de önemli köşe taşları haline geldi. Öğrencilerin bu eğitim kurumlarında batılı tarzda eğitim alması hedeflendi. Kazakistan'da bulunan Nazarbayev Liseleri (Nazarbaev Intellectual Schools) 2013 y1lı itibariyle 7 tane olmakla birlikte 2015 yılına kadar 20 okula çıkarıldı. Bu okullar Fen Bilimleri üzerine eğitim vermesinin yanı sıra en son teknoloji ile donatıldı. Eğitimcilerin büyük çoğunluğunun yabancılardan seçildi. Bu okullarla Kazakistan'ın gelecekteki yönetici grubunun yetiştirilmesini amaçlandı (Çetin, 2014: 49-51).

\section{Kazakistanlılık ve Kazaklık Açısından Milli Kimliğin İnşası}

Bağımsızlığın ilk yıllarında ülkedeki koşulları ve farklı etnik grupların varlığını gözeten bir ulus inşa stratejisi benimsendi. Nazarbayev, etnik bir kimliği vurgulamayan "Kazakistanlılık" kimliği, Kazakistan'ın yalnızca Kazakların yurdu olmadığını ülkenin tüm vatandaşlarını kapsadığının altını çizdi (Kuşcu, 2012: 186). Burada coğrafya-vatan birlikteliğinin yanı sıra bu topraklar üzerinde yaşayan halkların kültür, tarih, dil birlikteliğinin Kazakistan Cumhuriyetini meydana getirdiğini ifade etti. 1993 Anayasası, Kazakistan'ın tüm vatandaşlarına 
eşit haklar garanti etti. 1995 Anayasasında, cumhuriyet topraklarının sınırları belirlendi, tüm vatandaşların hakları garanti altına alındı. 1920'li yıllarda KASSR meydana geldiğinde Slavların yoğun göçü Kazak nüfusu toplamın \% 60'ından daha azını oluşturdu. Sovyet döneminde göç dalgasının yanı sıra, kolektifleşme ve yerleştirme siyaseti sonucu olarak Kazakların ağır nüfus kayıpları, neredeyse yüzde payını yarıya indirdi ve 1959 'da sadece $\% 30$ olarak görüldü. Slavlar (Ruslar, Ukraynalılar ve Beyaz Rusyalılar) \% 42, Almanlar neredeyse \% 4, Özbekler, Tatarlar, Uygurlar, Koreliler, Yahudiler, Polonyalılar ve diğer 90 etnik grup birlikte \% 10'luk çok daha küçük sayılarda nüfus temsil edildi. Sovyet dönemi göçleri demografik yapının değişmesine ve Kazakların baskın nüfusa sahip olması engellendi. Bütün olumsuz şartlara ve bağımsızlık döneminde resmî protestolara rağmen dört yüksek devlet dairesinin; başkan, başkan yardımcısı ve ilk başbakan yardımcısı Kazaklardan seçildi (Akiner, 1995: 71). Vatandaşlık yasaları, bağımsızlık sonrası dönemde Kazakistan'da ikâmet eden herkesin Kazakistan vatandaşlığına hak kazandığı ifade edildi. 1995 Anayasası'nın 14. maddesinde, etnik kökene dayalı ayrımcılık (Schartz, 2000: 492). "Herkes kanun ve mahkeme önünde eşittir. Köken, sosyal durum, görev ve mali durum, cinsiyet, 1rk, milliyet, dinî inanç, görüş, oturma yeri veya herhangi bir özellik nedeniyle kimseye ayrım yapılamaz." maddesiyle ortadan kaldırıld http://hukukbook.com/kazakistan-cumhuriyeti-anayasasi/,1995). Kazakistanlıl1k yasalarla vurgulansa da Sovyet dönemi enternasyonalizminin bir Rus yüzü olduğu gibi (etnik Ruslar için ayrıcalıklı bir konuma sahip olan), Sovyet sonrası Kazakistan devlet ideolojisinin Kazak yüzü vardı, Kazakları dilsel, demografik, politik ve kültürel iyileştirmeler öncelikliydi (Schartz, 2000: 492). Bir taraftan Kazakistan yurttaşlığı milliyet olarak yüceltilirken diğer taraftan Kazak kültürüne yapılan politika, uygulama ve projelerle "Kazaklık"a vurgu yapıldı. Burada Kazakistan birlik ve bütünlüğü, Kazakistan coğrafyası üzerinden gerçekleştirilmek istendi.

Yeni cumhuriyetin ulusal idaresi, liberal demokrasiyi, başkanlık sistemini, devletçi ve serbest piyasa modeli temelinde şekillendirildi. Bağımsızlık sonrası millî dilin ve kültürün kurtarılması, etnik azınlıklarla birlikte yaşama öngörüsü, millî tarih ve kahramanların öne çıkarılmasıyla millî kimlikleri güçlendirme eğilimine yönelikti (Musaoğlu, 2009: 265-266). Bu eğilimlere karşı tepkilerin oluşmaması için Nazarbayev, "Kazakların ulusal demokratik süreçlerle uyumlu olarak yeniden canlanması, insan haklarının gözetilmesi, eşit haklar temelinde diğer ulusların gelişmesi için vazgeçilmez bir koşuldu. Gelişiminin önündeki engellerle karşılaşmadan, Kazaklar şüphesiz diğer insanların çıkarlarını ve isteklerini anlayış ve saygı gösterecektir.” dedi (Schartz, 2000: 493).

2010 yılında Kazaklarla yapılan saha araştırmasında Sovyet dönemi sonrasını tanımlamak için 'Kazak olduktan sonra' ifadesi kullanıldı. Bu dönemde milliyetçi anlayış ile tarihsel, kültürel köklere dönerek "Kazaklık" misyonu üstlenildiği 
söylenebilir. Saha araştırmasında, Kazakların Sovyet döneminde de kendi gelenek göreneklerini koruduğu, Ruslar kendi geleneklerini, Kazakların da kendi geleneklerini korudukları ifade edildi. Diğer taraftan görüşmeciler, Sovyetlerin medeniyet olarak dayattıkları gelenekleri yapmaları istendiği, millı̂ kültürlerini değiştirmeye çalıştıkları ifade ettiler. Bağımsızlıkla birlikte özlerine dönerek millî gelenek göreneklerini çağdaşlaştırarak yerine getirdiklerini ifade ettiler. Burada farkındalıklarını anlatmaya, değişime mümkün olduğu kadar karşı koyduklarını göze çarpmaktadır. Kazakların kimliklerinin önemli bir yapıtaşı olan kültür, Kazakların belleğinde "Geleneklerini korumayan Kazak; Kazak değildir” sözüyle ifade edilir (Demirci, 2013: 284). Kazakistanlılık ve Kazaklık kavramlarının ortaya çıkma sebebi ise Kazakistan'ın nüfus yoğunluğunda etnik çeşitliliğin bulunması, birlik ve beraberliğin sürdürülmesinin istenmesi, farklı etnik gruplarından kaynaklanan problemlerin önüne geçmek amaçlıdır. Yönetim, yasalarla etnik grupların haklarını güvence altına aldığı gibi millî kimliğin gelişmesi amacıyla da Kazak tarihi ve kültürel kökenlere dönme eğilimi gösterdi.

\section{Sonuç}

Kazakistan'ın ilk devlet başkanı Nursultan Nazarbayev, milliyetçi politikalara ve uygulamalara öncelik vererek Kazakların millî kimliklerini ortaya koyma çalışmalarını çeşitli problemlere (nüfus, ekonomik şartlar vb.) rağmen başarıyla sürdürdü. Nazarbayev, yirmi sekiz yıllık yönetimi boyunca milli kimlik inşasında eksiklik ve problemleri belirleyerek aşama aşama çözümler getirdi. Bu dönemin ana hedefi, Kazakistan Cumhuriyetinin bağımsız, millî, laik, çağdaş ve dünyada gelişmiş ülkeler arasına girmesini sağlamaktı. Milliyetçilik, bu davanın gerçekleşmesinde ve hedefe ulaşma da sadece bir vasıtaydı. Kazakistan'da cumhuriyet dönemi, kimlik ile aidiyetin ve kültürel mirasın geri alınışına da tanıklık etti.

Kazakistan'ın millî kimlik inşasında Sovyet Birliği dönemi kesintiye uğratsa da Kazakların boy teşkilatları ve yedi ata geleneği olumlu katkılar yaptı. Boy teşkilatının kuralcılığı ve soya bağlayıcılığı etnik aidiyet duygusunu geliştirdi. Nazarbayev döneminde milliyetçilik anlayışı başlangıç ve süreç içerisinde farklı eğilimler göstermesinin sebebi, Sovyetlerin göç politikası ve ekonomik sorunlardı. Nazarbayev döneminin ilk çeyreğinde Kazakistanlılığı yani halkını 1rkî hususiyetlerden ziyade Kazakistan'a bağ lıl l̆ğ esas aldı. Bu süreç içerisinde Kazak tarih ve kültürüne dair araştırmaları ve millî kültürü destekledi, proje ve uygulamalar geliştirdi. Ülkenin bağımsızlık köklerini Sovyet Rusya hâkimiyeti ve Kazak Sovyet Sosyalist Cumhuriyetin aksine tarihteki Türk devletlerine ve Kazak Hanlığı'na dayandırdı. Nazarbayev Rusya'nın tarihî sembolik bağlarından kurtulmak amacıyla millî para tenge'nin kullanılması ve Kiril Alfabesi'nden Latin Alfabesi'ne geçilmesine dair somut adımlar attı. Modernliğin güçlü sembolü Latin alfabesine geçiş sürecini 2017 yılında başlattı. Nazarbayev, bu 
durumu yabancı dil öğrenimini ve internet kullanımının kolaylaştırılması olarak ülkenin iç ve dış huzuru için akılcı bir politika ile açıkladı. Sovyet döneminde ateizm propagandasıyla halkın inancı kırılmaya çalışılsa da bağımsızlık sonrası laiklik ilkesini benimsedi, İslamın halk içerisinde desteklenmesini (Kur'anKerim'in Kazakçaya çevrilmesi, Din İşleri Ajansı'nın kurulması, cami sayılarının artırılması vb.) sağladı. Bunun yanı sıra, Kazakların anayurda dönüşünün desteklenmesi ve Kazakistan'ın belli bölgelerine yerleştirilmesi veya bulundukları ülkelerde desteklenmesi kararları da Sovyet döneminden kalan problemlerinin (nüfus yoğunluğu, millî kültür gibi) çözümünde etkili bir çaba olduğu görülür.

Sonuç olarak Nazarbayev dönemi, milliyetçi anlayış ve kimlik inşası, iç ve özellikle diş olmak üzere birçok modelleme ve yeniliklerin uygulanma süreciydi. Nazarbayev, Kazak kimliğini geçmişten itibaren şekillenen kültürel siyasal ve tarihsel kökleriyle mukayeseli geliştirdi. Bu bağlantılarla millî kimlik, toprak ve onunla özdeşleşen halk fikri üzerine inşa edildi. Sorunların çözümü noktasında önemli adımlar atılarak diğer bağımsız Türk Cumhuriyetlerine nazaran hızlı bir gelişme ivmesi gösterdi.

\section{KAYNAKÇA}

Abdirassova, Gulmira; Kalamkas Kalıbayeva, Gazıza Şoybekova (2017). “Eski Türk Devletçiliğinin Bağımsız Devlet Kurma Felsefesinin Günümüz Kazakistan Politikasına Yansımaları", Milli Kültür Araştırmaları Dergisi (MİKAD), C.1, S.2, ss.10-17.

Aitymbetov, Nurken- Toktarov, Ermek- Ormakhanova, Yenlik (2015). “Nation-

Building in Kazakhstan: Kazakh and Kazakhstani Identities Controversy”, Bilig, No: 74, pp.1-20.

Akiner, Shirin (1995). The Formation of Kazakh İdentity, From Tribe to Nation State, Royal İnstitute of İnternational Affairs, London.

Alakel, Murat (2011). “İlk Dönem Cumhuriyet Türkiyesi Ulus İnşası Sürecinde Milliyetçilik ve Sivil- Etnik İkilimine Dair Teorik Tartışmalar", Gazi Akademik Bakış, C. 5, S. 9, ss. 1-30.

Arsal, Sadri, Maksudi (2018). Milliyet Duygusunun Sosyolojik Esasları, Ötüken Yayınları, İstanbul.

Çetin, Servet (2014). Kazakistan Ulus İnşa Sürecinde Türk Dilli Toplulukların Karşılaştırmalı Olarak Diaspora İlişkileri, (Yayınlanmamış Uzmanlık Tezi), T.C. Başbakanlık Yurtdışı Türkler ve Akraba Topluluklar Başkanlığı, Ankara. 
Demirci, Hikmet (2013). Sosyokültürel Değişim Sürecinde Kazak Ailesi ve Çocuk Terbiyesi (Sözlü Tarih Araştırması), (Yayımlanmamış Doktora Tezi), Erciyes Üniversitesi Sosyal Bilimler Enstitüsü, Tarih Anabilim Dalı, Genel Türk Tarihi Anabilim Dalı, Kayseri.

Ercilasun Kurmangaliyeva, Guljanat (2019). Sovyet Devrindeki Kazakistan'da Tarih Yazıcılı̆̆ı: Mitler ve Gerçekler, Gazi Kitabevi, Ankara.

Fragner, B.G. (2018). "Sovyet Milliyetçiliği: Orta Asya'nın Bağımsız Cumhuriyetlerine Kalan İdeolojik Miras", Orta Asya ve İslam Dünyasında Kimlik Politikaları, (Der. Willem van Schendel- Erik J. Zürcher), İletişim Yayınları, İstanbul.

Gündoğdu, Abdullah- Güler, Cafer (2017). "Kazakistan'ın Bağımsızlığının Tanınma Süreci ve Türk Kamuoyundaki Yankıları”, TAD, C. 36, S.61, 2017, ss.75-93.

Joldoshov, Altynbek (2019). "Kimlik ve Sınır: Orta Asya'da Sınır Sorunları", Türk Dünyası İncelemeleri Dergisi, C.19, S.2, ss. 303-326.

Kara, Abdulvahap (2017a). “Kazakistan Cumhuriyeti”, Bağımsızlıklarının 25. Yılında Türk Cumhuriyetleri (Siyasi, Ekonomik ve Kültürel İlişkiler), (Ed.Kara, Abdulvahap, Fahri Solak), Türk Dünyası Belediyeler Birliği (TDBB) Yayınları, İstanbul, ss. 73-131.

Kara, Abdulvahap (2017b). "Latin Alfabesine Geçiş”, Kazak Eli Dergisi, Kazak Türkleri Eğitim ve Araştırma Derneği Yayınları, İstanbul, S.5., ss.27-33.

Karadağ, Ahmet; Haluk Yaman (2018). "Üç Farklı Milliyetçilik”, Akademik Yaklaşımlar Dergisi, Kış, C. 9., S.2., ss. 84-108.

Kaya, Ayşe (2012). "SSCB Sonrası Coğrafyada Ulus İnşa Süreci: Kazakistan Örneği”, Alternatif Politika, Kasım, C. 4., S. 3., ss. 354-378.

Kesici, Özge (2011). “The Dilemma in the Nation-Building Process: The Kazakh or Kazakhstani Nation?”, Journal on Ethnopolitics and Minority Issues in Europe, Vol: 10, No: 1, pp. 31-58.

Kılıç, Murat (2007). “Erken Dönem Türk Milliyetçiliğinin Tipolojisi”, SDÜ Fen Edebiyat Fakültesi Sosyal Bilimler Dergisi, Aralık, S.16, ss.113-140.

Kuşçu, Iş̧ı (2012). “Kazakistan'da Ulus İnşası Sürecinde Etnik Geri Dönüş Göçü Siyaseti ve Etkileri”, Orta Asya'da Siyaset ve Toplum: Demokrasi, Etnisite ve Kimlik, (Ed. Turgut Demirtepe), Usak Yayınları, Ankara, ss. 175-207. 
Musaoğlu, Neziha (2009). “Orta Asya Cumhuriyetlerinde Dil, Ulusal Kimlik ve Demokrasi”, Trakya Üniversitesi Sosyal Bilimler Dergisi, Haziran, C.11, S. 1, ss. 261-273.

Nazarbayev, Nursultan (2012a). Tarihin Akışında, Redaksiyon: Zafer Kibar, Kazakistan Cumhuriyeti Büyükelçiliği Yayınları, Ankara.

Nazarbayev, Nursultan (2012b). Kazakistan Yolu, Redaksiyon: Zafer Kibar, Kazakistan Cumhuriyeti Büyükelçiliği Yayınları, Ankara.

Nazarbayev, Nursultan (2012c). Kritik On Yıl, Redaksiyon: Zafer Kibar, Kazakistan Cumhuriyeti Büyükelçiliği Yayınları, Ankara.

Nazarbayev, Nursultan (2017). “5. Kazak Kurultayı Konuşması”, Kazakeli Dergisi, S. 5, İstanbul, ss.12-25.

Nurken Aitymbetov, Ermek Toktarov, Yenlik Ormakhanova (2015). “NationBuilding in Kazakhstan: Kazakh and Kazakhstani Identities Controversy”, Bilig, Summer, No:74, pp. 1-20.

Osmanova, Usniya Khanym (2019). Sovyet Sonrası Kazakistan'da Etnik Siyasetin Yönetiminde Halk Asamblesi'nin Rolü, (Yayımlanmamış Yüksek Lisans Tezi), İstanbul Üniversitesi Sosyal Bilimler Enstitüsü, Siyaset Bilimi ve Uluslararası İlişkiler Anabilim Dalı, İstanbul.

Schatz, Edward (2000). “The Politics of Multiple Identities: Lineage and Ethnicity in Kazakhstan”, Europe-Asia Studies, Vol: 52, No: 3, pp. 489506.

Wimbursh, S. Enders (1986). Sovyet Orta Asyasında Soysuzlaştırma, (Çev. Dr. Yasin Ceylan), ODTÜ Mimarlık Fakültesi Basım İşliği, Ankara.

\section{Elektronik Kaynaklar:}

Bayer, Yalçın (2014). “Nazarbayev’den Dersler”,

https://www.hurriyet.com.tr/yazarlar/yalcin-bayer/nazarbayev-den-dersler$\underline{27330325}(25.03 .2020)$.

https://100kitap.kz/en/event/21 (12.03.2020).

https://ruh.kz/ru/latyn/ (15.02.2020).

http://hukukbook.com/kazakistan-cumhuriyeti-anayasasi/ (01.01.2020).

Raimbekova, Aliia (2018). “Kazakistan'da Güney Kazakistan Eyaletinin Adı 
Türkistan Eyaleti Olarak Değiştirildi”,

https://www.aa.com.tr/tr/dunya/kazakistanda-guney-kazakistan-eyaletinin-

adi-turkistan-eyaleti-olarak-degistirildi/1179026 (20.03.2020).

Wood, Colleen (2019). “Meeting the Kazakh Diaspora”,

https://thediplomat.com/2019/02/meeting-the-kazakh-diaspora// (20.03.2020). 